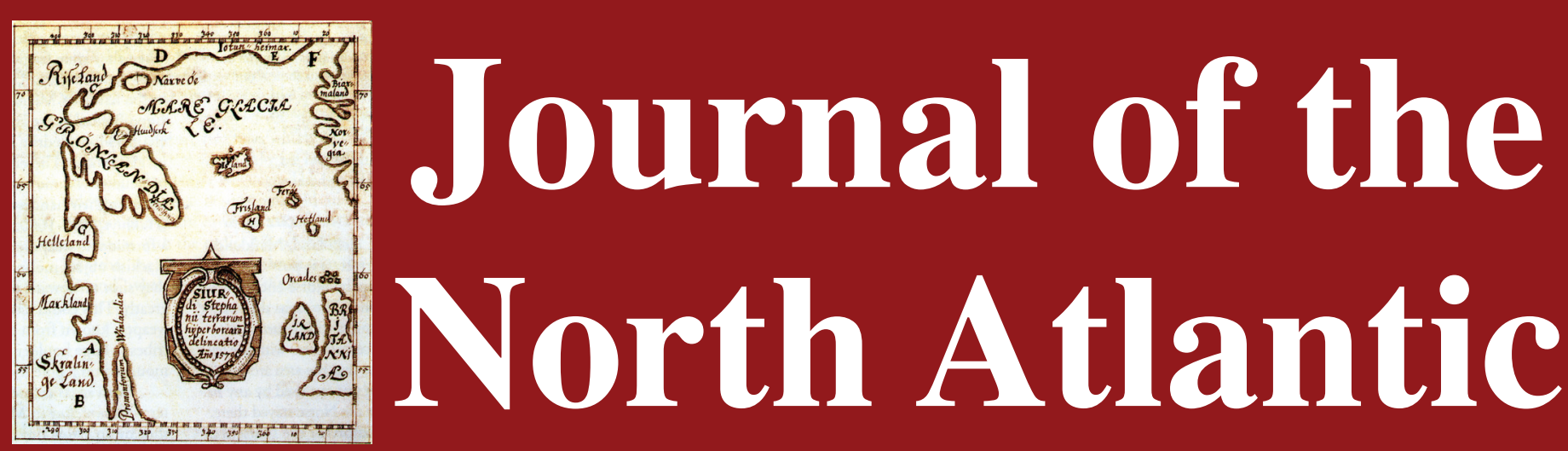

\title{
The Rediscovery of U 170: Runestones, Churchyards, and Burial Grounds in Sweden
}

\section{Shane McLeod}

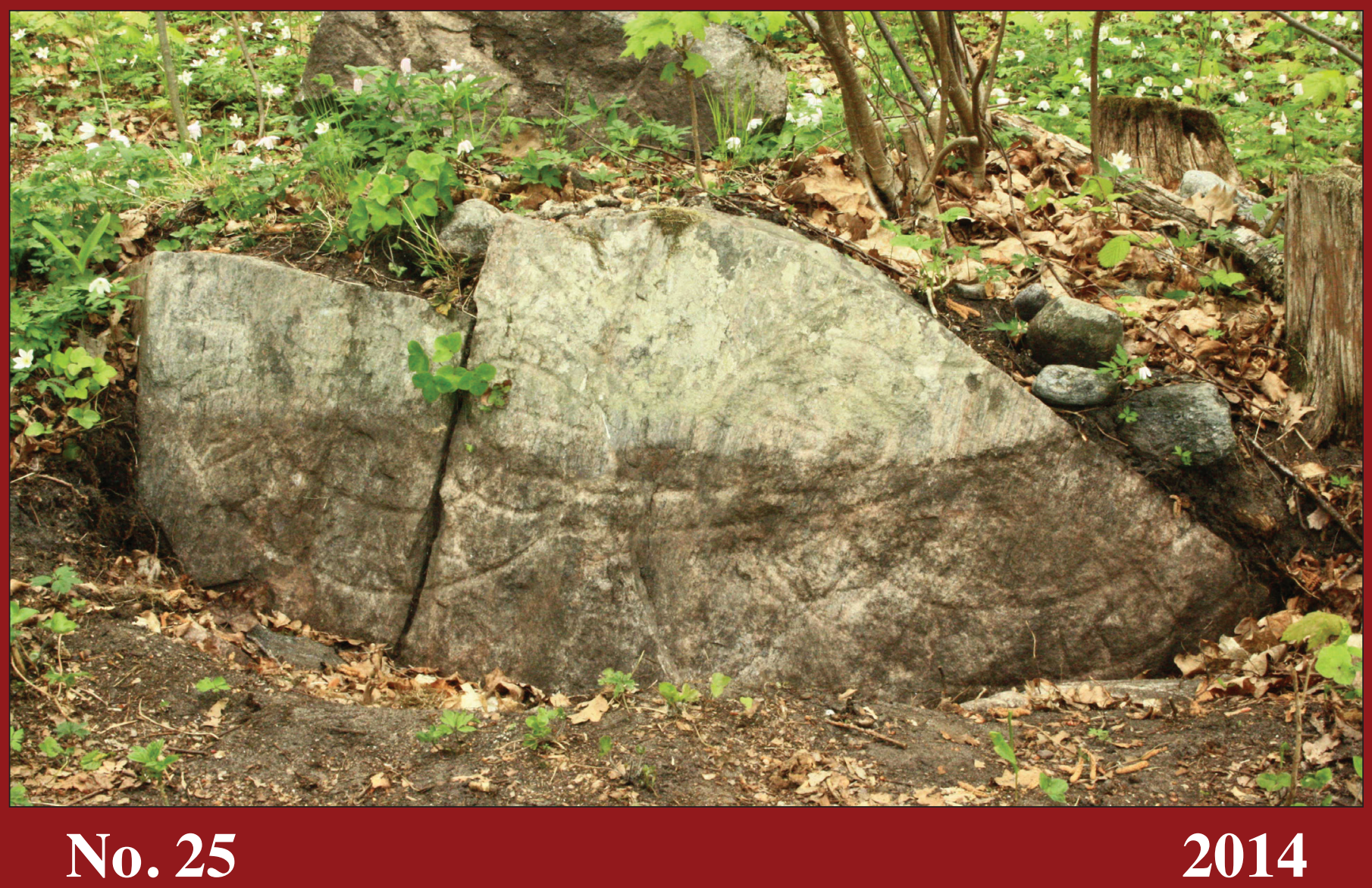

An archaeology and environmental history journal focusing on the peoples of the North Atlantic, their expansion into the region over time, and their interactions with their changing environments. 


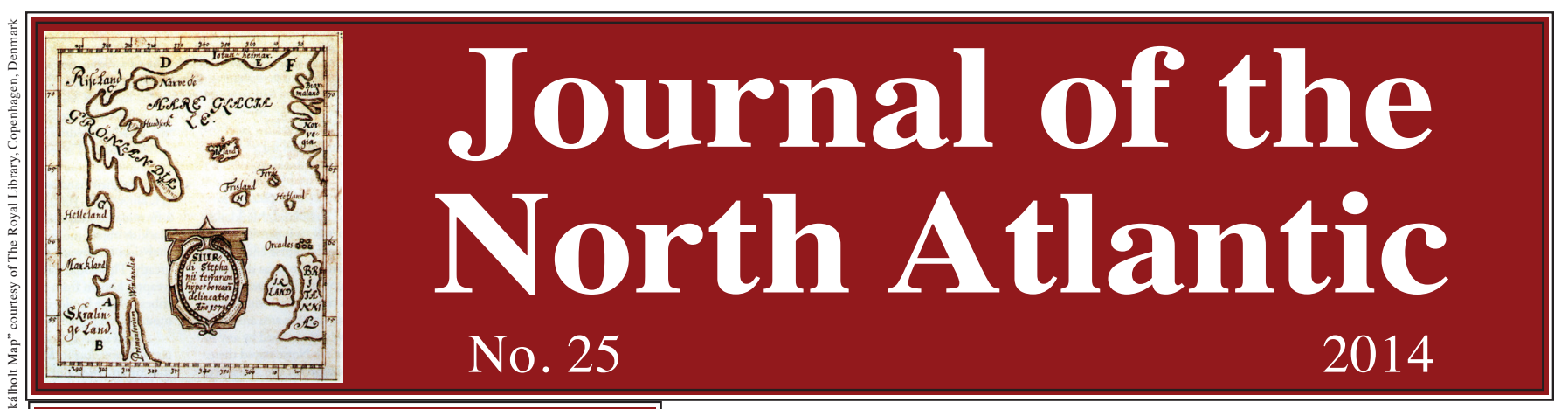

\section{Board of Editors}

Símun V. Arge, , Faroe Islands

Ian Armit, England, UK

Jette Arneborg, Denmark

Gerald F. Bigelow, USA

Steven A. Birch, Scotland, UK

Colin Breen, Northern Ireland

Mike J. Church, England, UK

Barry Cunliffe, England, UK

Christyann Darwent, USA

Jane Downes, Scotland, UK

Andrew J. Dugmore, Scotland, UK

Kevin J. Edwards, Scotland, UK

William W. Fitzhugh, USA, Senior Editor

Mark Gardiner, Northern Ireland, UK

Keith Goldfarb, USA, Production Editor

Erika Guttmann-Bond, The Netherlands

Agnar Helgason, Iceland

Lisa Hodgetts, Canada

Joerg-Henner Lotze, USA, Publisher

Niels Lynnerup, Denmark

Ditlev L Mahler, Denmark

Thomas H. McGovern, USA

Jacqui A. Mulville, Wales, UK

Georg Nyegaard, Greenland

Ulla Odgaard, Denmark

Astrid E.J. Ogilvie, USA, Senior Editor

Tadhg O'Keeffe, Ireland

Bjørnar Olsen, Norway

Richard D. Oram, Scotland, UK

Aidan O'Sullivan, Republic of Ireland

Robert W Park, Canada

Michael Parker-Pearson, England, UK

Peter E. Pope, Canada

Else Roesdahl, Denmark

Alexandra Sanmark, England, UK

Niall Sharples, Wales, UK

John Sheehan, Ireland

Ian A. Simpson, Scotland, UK, Senior Editor

Przemyslaw Urbanczyk, Poland

Orri Vésteinsson, Iceland

Alex Woolf, Scotland, UK

James Woollett, Canada
The Journal of the North Atlantic (JONA) is a multi-disciplinary, peer-reviewed and edited archaeology and environmental history journal focusing on the peoples of the North Atlantic, their expansion into the region over time, and their interactions with their changing environments. The journal-published online in the BioOne.org database and on the JONA website, and indexed in a full range of journal databases - serves as a forum for researchers, and as an information resource for instructors, students, and the intellectually curious who would like to learn about the latest research and study opportunities within the region.

The journal publishes a wide diversity of research papers, as well as research summaries and general interest articles in closely related disciplines, which, when considered together, help contribute to a comprehensive multi-disciplinary understanding of the historical interplay between cultural and environmental changes in the North Atlantic world. Specifically, the journal's focus includes paleo-environmental reconstruction and modelling, historical ecology, archaeology, ecology of organisms important to humans, anthropology, human/environment/climate interactions, climate history, ethnography, ethnohistory, historical analyses, discussions of cultural heritage, and place-name studies.

The journal publishes individual papers on an article-by-article basis. Whenever a manuscript has completed its peer review process and the article galley has been approved by the author, it will be immediately published online in the BioOne database and on the JONA website. This publishing model is also available for special volumes such as conference and symposium proceedings or other collections of papers. In effect, this means that articles are grouped online over time, i.e., the table of contents of volumes will grow as articles are posted online, which has the advantage of rewarding prompt authors, while enabling tardier authors to retain the option of being included in a special volume without delaying its publication.

The Journal of the North Atlantic's publishing format is versatile enough that authors can include supplementary files with their articles. These supplements may include dataset, figure, and table files (e.g., files requiring a larger than normal journal page size, such as large maps), as well as text and protocol files, audio and video files (e.g., for ethnographic studies), and even Powerpoint files.

The Journal of the North Atlantic (Online ISSN \#1935-1933, Print ISSN \#1935-1984), with an international editorial board, is a collaborative publishing effort of the Eagle Hill Institute, PO Box 9, 59 Eagle Hill Road, Steuben, ME 046800009 USA. Phone 207-546-2821, FAX 207-546-3042. E-mail: office@eaglehill.us. Website: www.eaglehill.us/jona. Copyright (C) 2014, all rights reserved. On-line secure subscription ordering: rate per year is $\$ 40$ for individuals, $\$ 32$ for students, \$180 for organizations. Authors: Instructions for authors are available at www.eaglehill.us/jona. The Eagle Hill Institute (Federal ID \# 010379899) is a tax exempt 501(c)(3) nonprofit corporation of the State of Maine, USA.

Cover Image: The remains of U 170. Photograph (C) Aurore McLeod. 


\title{
The Rediscovery of U 170: Runestones, Churchyards, and Burial Grounds in Sweden
}

\author{
Shane McLeod*
}

\begin{abstract}
This note reports on the recent rediscovery of runestone U 170 near Bogesund in Sweden. In particular, the position of the monument within the $11^{\text {th }}$-century landscape is examined in light of the informative text that provides important information on early churchyard burial in central Sweden. The likely reason for placing a Christian monument at the edge of a pre-Christian burial ground is commented upon, including the likelihood of continued ancestor worship, as is its relationship to water.
\end{abstract}

\section{Introduction}

The rediscovery of runestone $\mathrm{U} 170$ between Bogesund's brygga (Bogesund's jetty) and the small village of Bogesund in the Stockholm archipelago (Fig. 1) in late April 2013 was a fortuitous discovery for a number of reasons. Obviously, the rediscovery of the stone by Torun Zachrisson and a group of students from Stockholm University is itself a remarkable event as $\mathrm{U} 170$ had been missing for about three hundred years (Källström 2013). Furthermore, the informative text on the stone can now be assessed with reference to the location of the stone within the landscape. The text and the position of the runestone help to shed some light on local attitudes to past beliefs and the landscape during the transitional period when Christianity began to be more widely accepted in central Sweden.
U 170 was known from an illustration made by Johan Peringskiöld in the late $17^{\text {th }}$ century (Fig. 2), but the stone and its exact location were later lost. The rediscovered base of the stone matches Peringskiöld's drawing, with approximately the bottom quarter of the inscription surviving. The small stones packed in around the base of $U 170$ suggest that the stone remained in its original location (Fig. 3). Even when the drawing was made, the stone appears to have had some significant cracks, and it possibly fell apart not long after the drawing was made (Wessén and Jansson 1940-1943:258). A comparison of the drawing and the surviving stone makes it obvious that what remains today is the section below the two lowest horizontal cracks in the drawing (Fig. 4). A limited excavation around U 170 in June 2013 failed to find any additional fragments with carvings (M.

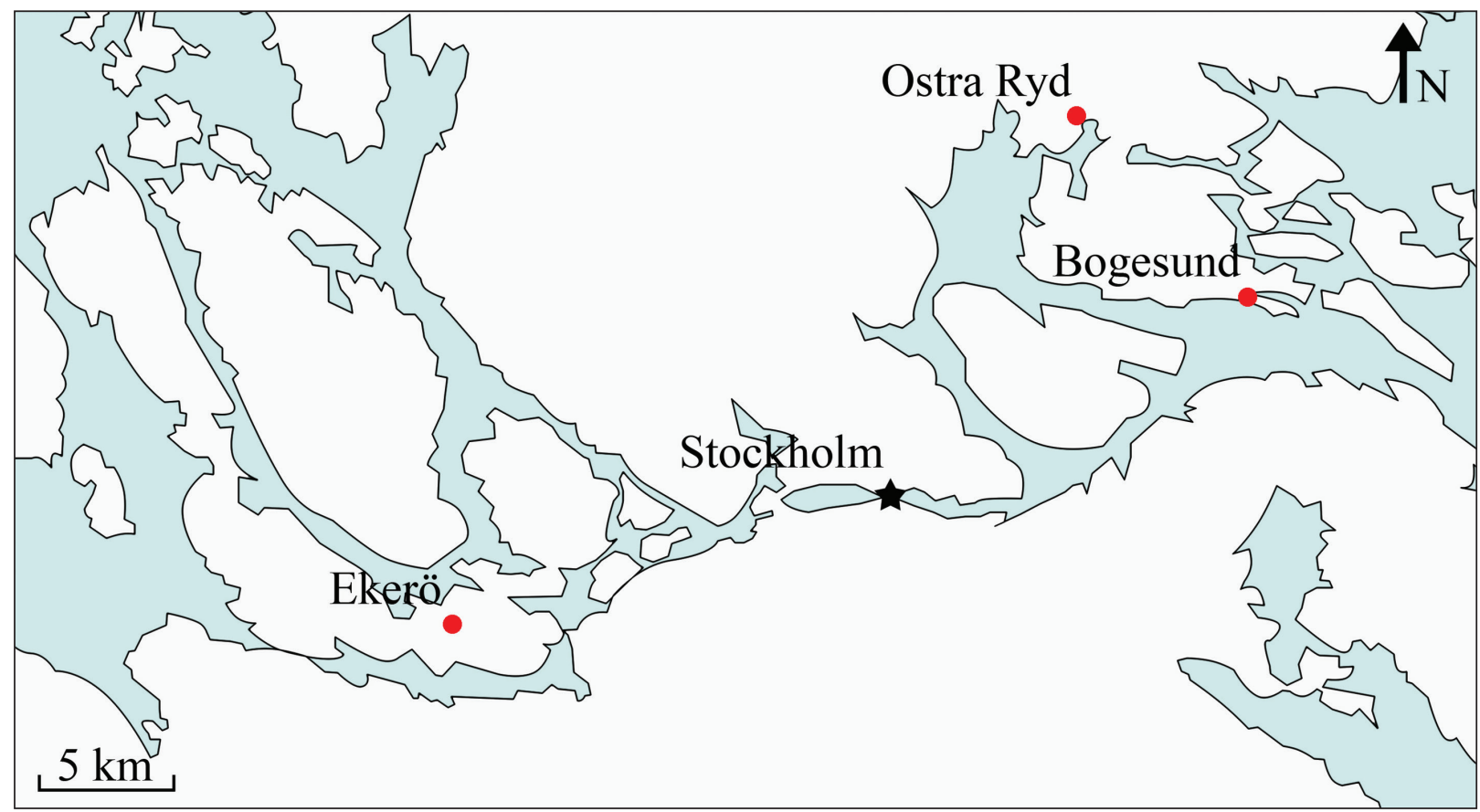

Figure 1. Map of the places named in the text. Map drawn by Aurore McLeod.

*Impact Research Fellow, History and Politics, The University of Stirling, FK9 4LA, Scotland, UK; s.h.mcleod@stir.ac.uk. 


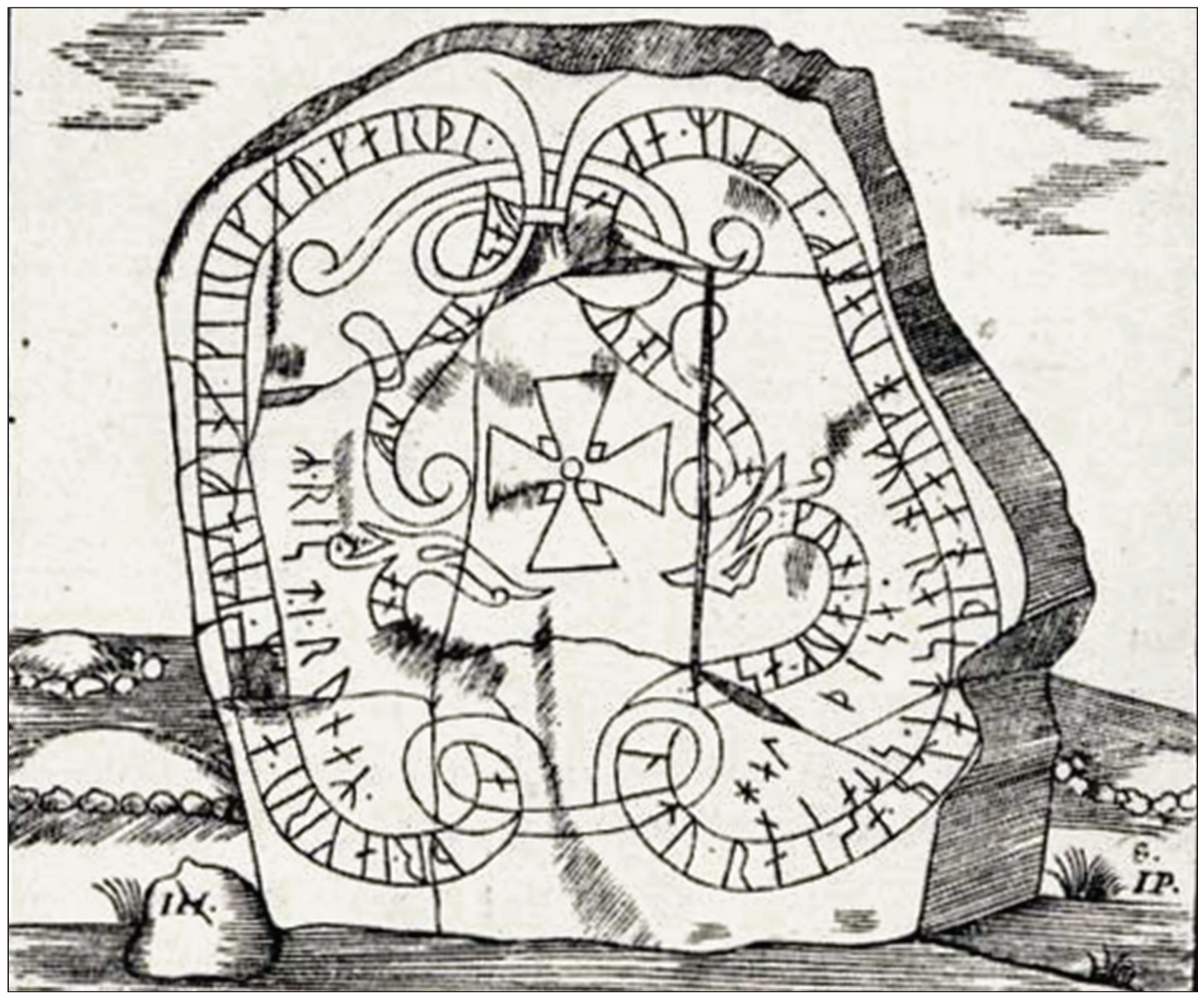

Figure 2. U 170 after Peringskiöld's original illustration (after B 223). After Wessén and Jansson (1940-1943:259).

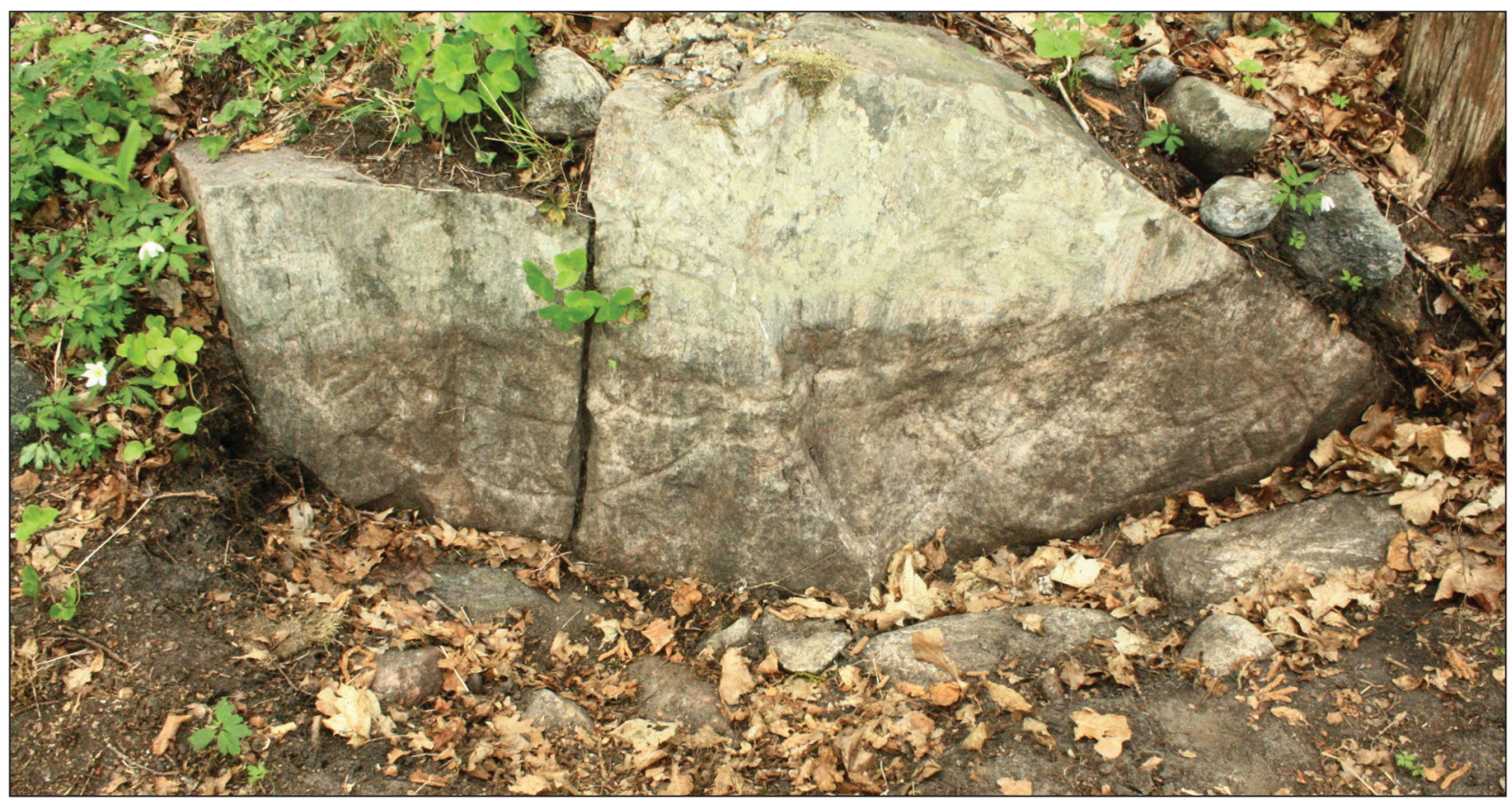

Figure 3. Deliberately placed small stones at the base of U 170. Photograph by Aurore McLeod. 
Källström, Swedish National Heritage Board, Stockholm, Sweden, 2013 unpubl. data).

The text of the inscription, as recorded in Peringskiöld's drawing, read:

\section{Latin transliteration}

: kuni * auk * asa * litu * raisa * sta -- pina * auk * hualf * iftiR * akn- -un sin an ... ...aupr * i akru * a- $-\mathbf{R} *$ krafin * $\mathbf{i}$ * kirikiu*karpi * fastulfR * risti * runaR * kuin * raisti * stainhal pisa *

Old Norse transcription

Gunni ok Asa letu rceisa stcein penna ok hvalf aeftiR [Øynd, s]un sinn. Hann [varð d]auðr i AEikrøy(?). [Hann eR] grafinn i kirkiugarði. FastulfR risti runaR. [Gunni] roeisti stceinhall pessa. (Wessén and Jansson 1940-1943:258)

\section{English translation}

Gunni and Ása had this stone and the vault raised in memory of Eyndr, their son. He died in Eikrey(?). $\mathrm{He}$ is buried in the churchyard. Fastulfr carved the runes. Gunni raised this stone rock-slab. (Samnordisk runtextdatabas)

Based on Peringskiöld's illustration, the runestone is thought to belong to Anne-Sofie Gräslund's
Pr 3 style group (an Urnes style) and dated to the mid-11 ${ }^{\text {th }}$ century, ca. 1045-1075 (Samnordisk runtextdatabas; Gräslund 2006:126). The runestone is thus a very early reference to the use of churchyard burial in central Sweden. It is thought that Eikrøy refers to Ekerö in Lake Mälaren about $30 \mathrm{~km}$ to the southwest (Wessén and Jansson 1940-1943:261-2). If Eikrøy does refer to Ekerö, then it may suggest that churchyard burial was not then available closer to Bogesund to bury Eyndr. It also demonstrates that Eyndr's family had a connection to both places that warranted the erection of public monuments. Alternatively, Cecilia Ljung has suggested that although Eyndr died in Ekerö he may have been buried in the parish church of Östra Ryd where two other runestones (U 166 and $U$ 167) raised by the same family have been recovered (Ljung 2012:2). However, it should be noted that these stones were not in their original locations as they were actually incorporated into the fabric of the church (Wessén and Jansson 1940-1943:251, 253), and it cannot be certain that churchyard burial was then available in Östra Ryd. Ljung (2012:5) has also suggested that hvalf monuments like the one raised in the churchyard for Eyndr demonstrate a likely connection with southeastern England during the reign of Knútr and that those buried in such monuments were either in England

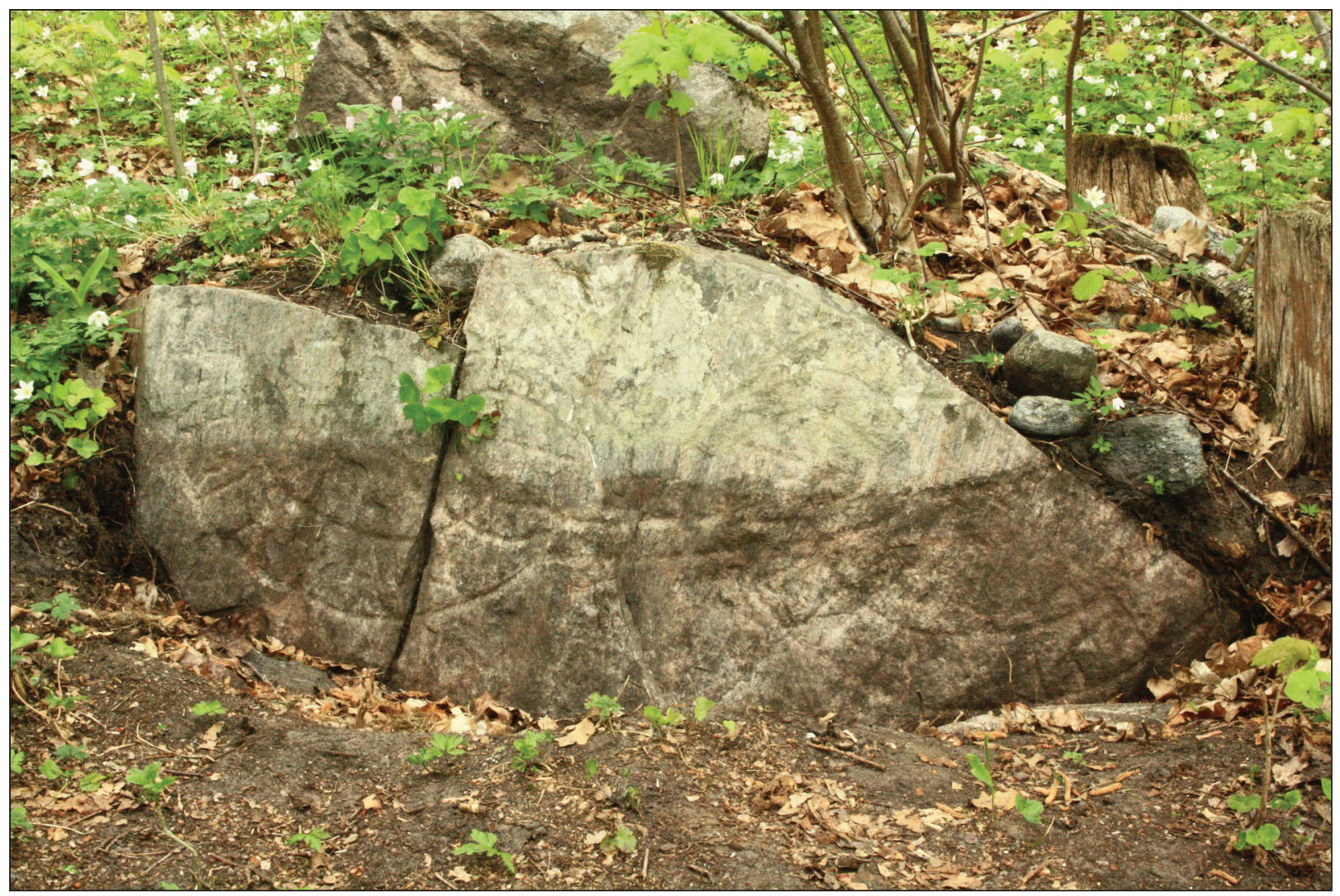

Figure 4. The remains of U 170. Photograph by Aurore McLeod. 
or related to people who had been there. Although translated as "vault", at the time the term possibly referred to a stone cist grave with a vault shape (Ljung 2012:1, Wessén and Jansson 1940-1943:262). ${ }^{1}$ Consequently, Gunni and Ása erected two visible stone monuments to their son, and it is possible that the raised grave slab in the churchyard also contained a runic inscription, like those at Hov in Östergötland (Ljung 2012:1-2). The connection with England is traced through a comparison of stone sculpture in the Ringerike style in England and Sweden (Ljung 2012:4-5). Considering the stylistic dating of U 170 to ca. 1045-1075, it may be presumed that, if Ljung is correct, it was one or both of Eyndr's parents who had been in England during the reigns of Knútr or his sons Harald and Hardeknud (r. 1016-1042) rather than Eyndr himself.

\section{Discussion}

It has also been noted that a primary function of runestones in eastern Sweden was to declare that the individual or family were Christian, which is clearly the case with the text of U 170 (Sawyer 2000:148). The burial of Eyndr in a churchyard and the prominent cross placed in the center of his commemorative runestone are particularly interesting in light of his parent's decision to erect his runestone at the edge of a pre-Christian burial ground (ca. 550-1050). Although the burial ground can be difficult to discern today due to the trees and shrubs (Fig. 5; Fornsök, n.d.), burial mounds with stone kerbs are clearly depicted in Peringskiöld's drawing (Fig. 2). By placing the runestone at the edge of the gravefield Gunni and Ása were combining the Christian monument with a sacred place containing the remains of the ancestors. In this way, although the physical remains of the commemorated were buried elsewhere, a physical presence at the traditional burial ground was maintained, providing some form of physical and emotional link with the past. Considering that "Place is [and almost certainly was] an important factor in the creation of memory and identity" (Leonard 2011:43), then it is likely that the burial ground at Bogesund contained the remains of some of Eyndr's ancestors, that the maintenance of their memory and the identity of the family unit were considered important, and that runestone $\mathrm{U}$ 170 would help to continue the connection to that place and its history. Zachrisson (1998:126-159) has noted that many of the runestones were raised on magnates farms to which their social identity was tied, and in the case of U 170 it would seem that their social identity could also be linked to burial

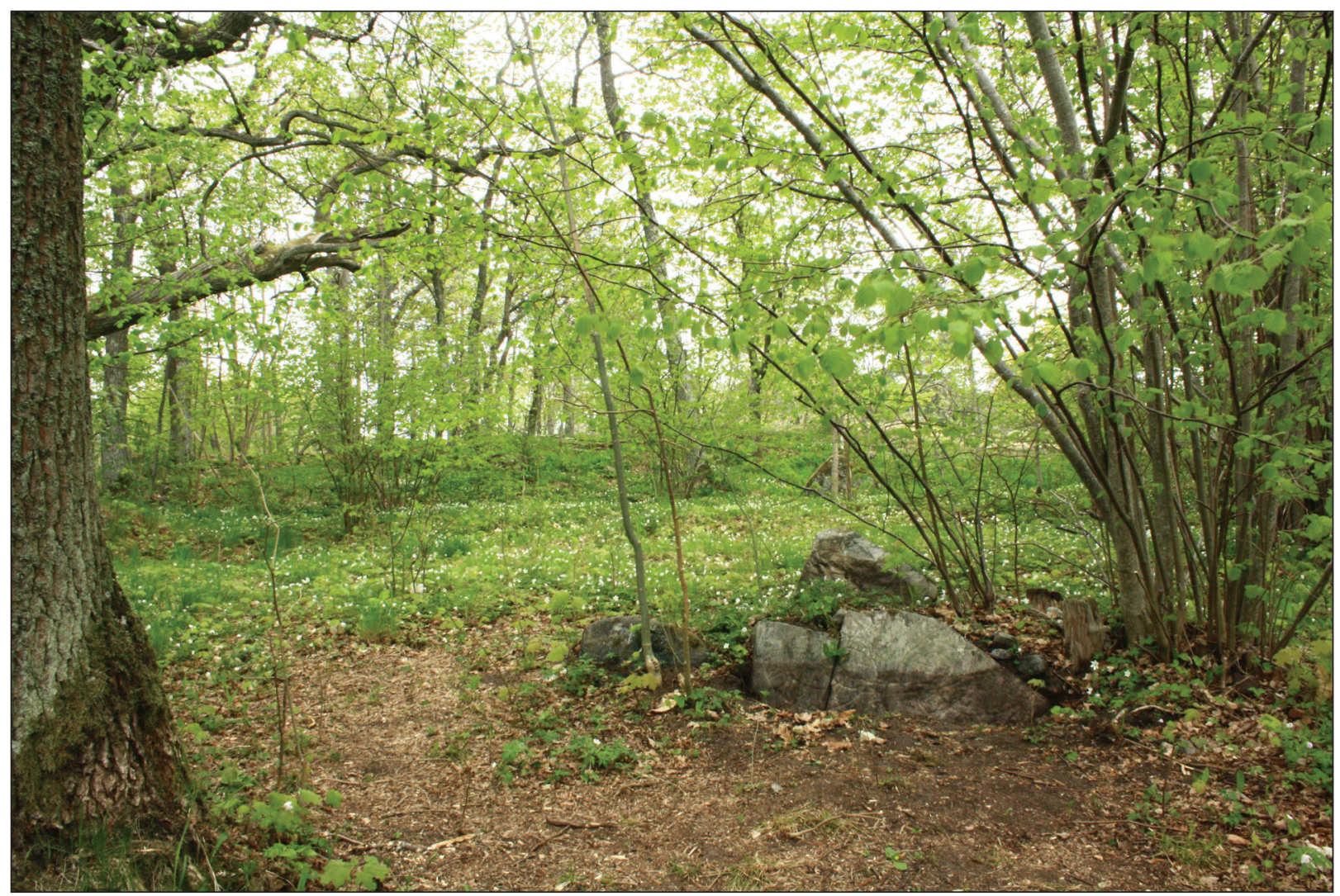

Figure 5. U 170 and the burial ground behind it. Photograph by Aurore McLeod. 
grounds. Other explicitly Christian (in either their text or decoration) runestones placed in or near preChristian burial grounds, such as U 60, Sö 106, Sm 5, Sm 29, and Sm 42, may have served a similar purpose of maintaining a connection between a family and the burial ground of their ancestors.

U 170 clearly demonstrates that runestones were part of the cultural landscape of the transitional period during which Christianity was adopted by a growing number of people in Sweden, and the placement of the Christian monuments in or at the edges of important spaces in the "metaphysically charged" (recent or concurrently) pre-Christian landscape was surely significant (Sanmark 2010:176; cf Brink 2001:81-82). The placement of these Christian runestones in pre-Christian burial grounds provided a powerful link to past practices and perhaps helped to connect these places to the new emerging belief system. Indeed, the placement of the runestones may have helped to consecrate the burial grounds (Gräslund 1996:120). Lydia Klos (2009:350) has taken this notion further and claims that the majority of runestones were originally placed at grave-fields, which allowed them to continue as important places in the early Christian period. However, it should be noted that the number of stones at grave-fields has probably been overemphasized by Klos at the expense of other locations such as roads (Larsson 2010:249-253). Zachrisson (1998:194-200) has suggested that runestones placed on farm boundaries offered protection to the farm, both by the person commemorated on the stone and the Christian ornamentation and text. Consequently, the placing of runestones in or on the boundary of a burial ground may have not only consecrated the cemetery but also protected it. If monuments are regarded as "physical safeguards of the actions and beliefs of communities or individuals" (Leonard 2011:44), then the text and iconography of U 170 clearly expresses a Christian belief, but its placement strongly suggests that earlier burial grounds could co-exist with the new belief system.

It has been noted that runestones were public monuments, with many marking farm boundaries where they crossed the main road into the farm, often at bridges since boundaries regularly followed water-courses (Zachrisson 1998:174-194). This public nature of the monuments has led to the suggestion that they served as inheritance documents (Sawyer 2000:47-91). In the case of U 170, it was also located close to water and a road, both of which enhanced the likelihood of the runestone being seen and read. Gunnar Ekholm (1950:138-139) argued that many runestones ended up adjacent to earlier burial grounds by default due to the use of communication networks for the placement of each. However, I consider the decision to place U 170 near a burial ground to have been deliberate, and that its location suggests that the pre-Christian grave-field continued to be visited even if it was no longer in active use, presuming that other locals were also starting to adopt churchyard burial. It is thought that in preChristian Norse belief ancestors were believed to appear close to or in their graves and that they needed to be looked after by the living (Sanmark 2010:164166). There is also evidence that those in mounds were remembered on feast days, and that pre-Christian burial grounds were visited to celebrate and engage with the ancestors. In chapter 14 of the Saga of Hákon the Good in Snorri Sturluson's Heimskringla (written ca. 1230) about the tenth-century king of Norway, people at ritual feasts "drank toasts to their kinsmen, those who had been buried in mounds, and these were called minni (memorial toasts)" (Finlay and Faulkes 2011 98). The post-Christian Older Laws of Gulathing, which were first written down in the mid- $13^{\text {th }}$ century but represent in part earlier laws, outlawed sacrifices to burial mounds in Chapter 29 (Larson 1935:57). Chapter 23 of these laws also mention feasts for the dead at burial mounds, to which priests were directed to attend, demonstrating that such practices continued into the Christian period (Larson 1935:52-53). Gräslund (2001:227-231) has suggested that external cists found at the edges of some Viking Age burial mounds in Sweden, some of which contained animal bones and potsherds, were used for food and drink offerings to the dead. There is also some evidence that ritual meals or food deposits occurred at runestones (Ljung and Thedeen 2012). If something similar occurred at U 170, then it would have allowed a feast or sacrifice to take place where tradition demanded, near the pre-Christian burial mounds. Finally, the Later Law of Gulathing included a direction not to wake up those living in burial mounds (Sanmark 2010:172), which again suggests that people continued to visit pre-Christian grave-fields well into the Christian period. Indeed, Alexandra Sanmark (2010:171) has characterized burial mounds as "places for communication between the dead and the living", and this communication apparently continued into the Christian period. Based in part on their shape, Klos (2009:345) has suggested that runestones themselves were used for this purpose, acting as a door allowing communication with the dead, and also as a threshold to protect the living against spirits. Regardless of the validity of Klos' suggestion, Christian runestones erected at pre-Christian grave-fields should still be considered 
as public monuments that were expected to be seen and read (cf. Klos 2009:349-350). Such public display help to explain the considerable time and effort, and therefore expense, of preparing, carving, coloring, and erecting a runestone (Herschend 1999:15).

This notion of runestones as public monuments intended to be admired and read (Ekholm 1950:144145) makes another aspect of the location of $U 170$ very interesting. $\mathrm{U} 170$ is a timely reminder of the importance of water in the medieval period: there is a Viking Age road behind the stone (Fig. 6), but the inscription faces a field which had been part of a bay from which the sea could be accessed (Fig. 7). Magnus Källström has suggested that the stone acted as a landmark for seafarers (2013). Considering that runestones are thought to have been brightly painted (Prainsson 1999), and a comparison of Peringskiöld's drawing and the surviving stone suggests that it would have stood around $1.5 \mathrm{~m}$ high, this is quite likely to be correct. However, a contributing

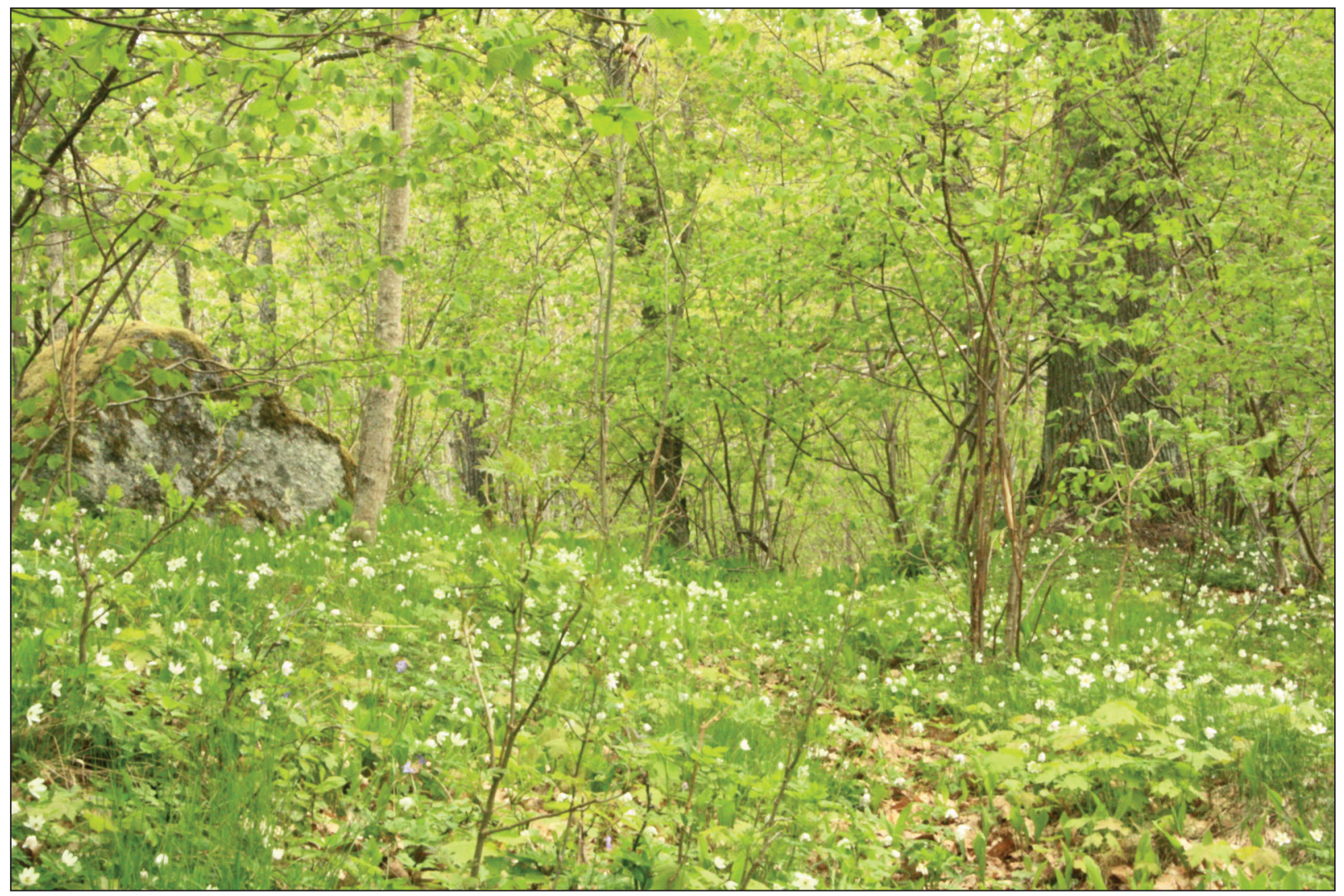

Figure. 6. Evidence for a road behind U 170. Photograph by Aurore McLeod.

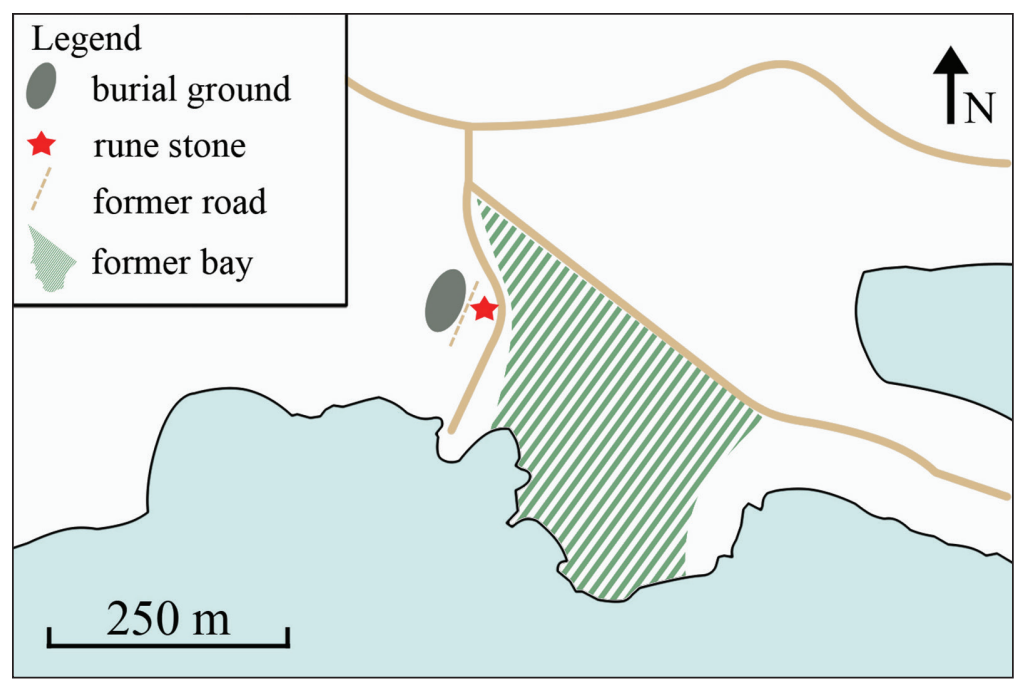

Figure. 7. Map of the landscape around $U$ 170. Map drawn by Aurore McLeod. 
factor in the orientation of the stone is likely to have been the likelihood of the stone being read, thereby justifying the cost of the stone and ensuring that people learnt about Eyndr and his family. This reasoning suggests that U 170 was just as likely to be read by people coming from the shore as it was by people using the road behind the stone. An excavation carried out around U 170 in June 2013 which revealed that a small area in front of the stone had been paved with small round stones strengthens this suggestion. The excavation was not extensive enough to be conclusive, but the paved area could be part of a larger structure, perhaps a path that led from the road to the seashore (M. Källström, Swedish National Heritage Board, Stockholm, Sweden, 2013 unpubl. data). If this was the case, then U 170 combined visibility from water with visibility from land, and it suggests that as many people were likely to read it if it faced the water as if it was turned around to face the road.

The rediscovery of runestone U 170 near Bogesund's brygga allows the inscription that contains crucial information about conversion-period Sweden to be assessed in conjunction with the location of the monument within the landscape. The stone is situated where three features - a road, bay, and burial ground-meet, thereby maximizing the opportunity for $U 170$ to be seen and read. The location also makes it clear that a desire for some physical and emotional connection with past practices existed. Placing the runestone on the edge of a pre-Christian burial ground allowed a link with the ancestors to be maintained while following the new Christian burial custom elsewhere.

\section{Acknowledgments}

Chiefly I would like to thank Magnus Källström at Riksantikvarieämbetet for taking the time to meet with me and alerting me to the rediscovery of $U$ 170, and for later providing information about the subsequent excavation at the site. Torun Zachrisson, who re-discovered the stone and led the small excavation, was very gracious in allowing this small contribution to proceed in advance of her full report. I would also like to thank Alison Leonard, Cecilia Ljung, and Alexandra Sanmark for providing copies of their articles. This article has benefitted greatly from the efforts of the two reviewers and the editor, Laila Kitzler Åhfeldt. All errors and oversights remain my responsibility. The Bogesund runestone was visited during a research trip in May 2013 funded by the Australia Research Council's Centre of Excellence for the History of the Emotions, based at the University of Western Australia. Finally, I thank my wife and daughter for allowing me to drag them out to runestones.

\section{Literature Cited}

Brink, S. 2001. Mythologizing landscape: Place and space of cult and myth. Pp. 76-112, In M. Stausberg (Ed.). Kontinuitäten und Brüche in der Religionsgeschichte. Festschrift für Anders Hultgård zu seinem 65. Geburtstag am 23. 12. 2001. Walter der Gruyter, Berlin, Germany.

Ekholm, G. 1950. Var Restes Runstenarna? Fornvännen 45:137-147.

Finlay, A., and A. Faulkes (tr.). 2011. Snorri Sturluson, Heimskringla, Vol 1: The Beginnings to Óláfr Tryggvason. Viking Society for Northern Research, London, UK.

Fornsök. No date. RAÄ-nummer Östra Ryd 6:1. Swedish National Heritage Board: Riksantikvarieämbetet. Available online at www.fmis.raa.se/cocoon/fornsok/ search.html. Accessed 24 July 2013.

Gräslund, A-S. 1996. Some aspects of the christianization of central Sweden. Pp. 117-124, In J. Pentikäinen (Ed.). Shamanism and Northern Ecology, Religion and Society 36. Walter der Gruyter, Berlin, Germany.

Gräslund, A-S. 2001. Living with the dead: Reflections on food offerings on graves. Pp. 222-235, In M. Stausberg (Ed.). Kontinuitäten und Brüche in der Religionsgeschichte. Festschrift für Anders Hultgård zu seinem 65. Geburtstag am 23. 12. 2001. Walter der Gruyter, Berlin, Germany.

Gräslund, A-S. 2006. Dating the Swedish Viking-Age rune stones on stylistic grounds. Pp. 117-139, In M. Stoklund, M.L. Nielsen, B. Holmberg, and G. Fellows-Jensen (Eds.). Runes and Their Secrets: Studies in Runology, Museum Tusculanum Press, Copenhagen, Denmark.

Herschend, F. 1999. Runestones as a social manifestation. Pp. 15-19, In E. Lietoff (Ed.). Runestones: A Colourful Memory. Museum Gustaviaum, Uppsala, Sweden.

Klos, L. 2009. Runenstein in Schweden: Studien zu Aufstellungsort und Funktion. Erganzungsbande zum Reallexikon der Germanischen Altertumskunde 64. Walter de Gruyter, Berlin, Germany.

Källström, M. 2013. Runfynd bland blåsipporna, In K-Blogg, Swedish National Heritage Board: Riksantikvarieämbetet. Available online at www.k-blogg. se/2013/04/26/runfynd-bland-blasipporna/. Accessed 24 July 2013.

Larson, L M. 1935. The Earliest Norwegian Laws: Being the Gulathing Law and the Frostathing Law. Columbia University Press, New York, NY, USA.

Larsson, M.G. 2010. [Review of] Lydia Klos. Runensteine in Schweden: Studien zu Aufstellungsort und Funktion. Erganzungsbande zum Reallexikon der Germanischen Altertumskunde 64. Futhark: International Journal of Runic Studies 1:249-253.

Leonard, A. 2011. Vikings in the prehistoric landscape: Studies on mainland Orkney. Landscapes 12.1:42-68.

Ljung, C. 2012. Early Christian grave monuments and the $11^{\text {th }}$-century context of the monument marker hvalf. Pp. 1-7. Available online at http://www.academia. edu/792841/Early_Christian_grave_monuments_and the_11th-century_context_of_the_monument_marker_hvalf. Accessed 24 July 2013. 
Ljung, C., and S. Thedéen. 2012. Without a trace? Rituals and remembrance at rune stones. Pp. 9-18, In R. Berge, M.E. Jasinski, and K. Sognnes (Eds.). N-Tag Ten: Proceedings of the $10^{\text {th }}$ Nordic TAG conference at Stiklestad, Norway 2009. BAR International Series 2399. Archeopress, Oxford, UK.

Sanmark, A. 2010. Living on: Ancestors and the soul. Pp. 162-184, In M. Carver, A. Sanmark, and S. Semple (Eds.). Signals of Belief: Anglo-Saxon Paganism Revisited. Oxbow Books, Oxford, UK.

Sawyer, B. 2000, The Viking-Age Rune-Stones: Custom and Commemoration in Early Medieval Scandinavia. Oxford University Press, Oxford, UK.

Samnordisk runtextdatabas: Rundata 2.5. No date. Available online at http:/www.nordiska.uu.se/forskn/samnord.htm. Uppsala University. Accessed 24 July 2013

Wessén, E, and S. B. F. Jansson. 1940-43. Upplands runinskrifter, Sveriges runinskrifter vols. 6. KVHAA. Almqvist \& Wiksell, Stockholm, Sweden. Available online at www.raa.se/kulturarvet/arkeologi-fornlamningaroch-fynd/runstenar/digitala-sveriges-runinskrifter/ digitala-sveriges-runinskrifter-publicerat/. Accessed 24 July 2013.

Zachrisson, T. 1998. Gård, gräns, gravfält. Sammanhang kring ädelmetalldepåer och runstenar från vikingatid och tidigmedeltid i Uppland och Gästrikland. Stockholm Studies in Archaeology 15. Institutionen för arkeologi och antikens kultur, Stockholm, Sweden.

Porhallur Prainsson. 1999. Traces of Colour. Pp. 21-30, In E. Lietoff (Ed.). Runestones: A Colourful Memory. Museum Gustaviaum, Uppsala, Sweden.

\section{Endnote}

${ }^{1}$ Alternatively, Klos (2009:182) translates hvalf as Grabplatte (grave-plate), i.e., a slab or stone at the grave containing an inscription. 